\title{
FORMATION OF ASSERTIVENESS AS A MEANS OF EQUALIZATION OF COMMUNICATIVE INTERACTION IN POLYETHNIC SPACE OF UKRAINE
}

\section{Bielavin S. P.}

\section{INTRODUCTION}

The growth of the scientific interest of social psychology in questions of interethnic relations is reflected in the development of a number of problems: the social psychology of the community, its place in the system of interethnic relations ${ }^{1}$, interpersonal and intergroup perception, in particular in the area of the interconnection of national identity and language ${ }^{2,}{ }^{3}$, the phenomenology of ethnic stereotypes in the space of interethnic relations ${ }^{4,5}$, socio-psychological processes and mechanisms of social perception.

Social perception in them acts as a regulator of communication and the structure of the perception of "other" people and groups: perception of the context of the situation, reflection, interpretation, evaluation in it of yourself and "other".

In this sense, a certain place in the structure of the perception of the "other" is the principle of reflected subjectivity ${ }^{6}$ as an ideal representation of one person in another, as a source of transformation meaningful to another situation. We are talking about "the personal being of man in the world, in the life of others, in the extension of a person in another person."

The ability of a person does not depend on external influences and assessments, the ability to respond adequately to acute situations, to independently regulate and be responsible for his own behavior, the ability to defend his mind without violating the rights of another person, is

1 Васютинський В. О. Російськомовна спільнота в Україні: загрози ідентичності і постави щодо інтеграції / В.О.Васютинський // Науковий вісник Львівського державного університету внутрішніх справ. - Львів, 2008. - Вип.1. - С. 37-45.

2 Голота А. С. Соціально-психологічні особливості етнонаціональної ідентичності українськоросійських білінгвів : автореф. дис. на здобуття наук. ступеня канд. психол. наук : 19.00.05 «Соціальна психологія; психологія соціальної роботи» / А. С. Голота - К., 2012. - 18 с.

3 Донцов А. И. Язык как фактор этнической идентичности / А. И. Донцов, Т. Г. Стефаненко, Ж. Т. Уталиева // Вопросы психологии. - 1997. - № 4. - С. 75-86.

${ }^{4}$ Слюсаревський М. М. Ілюзії і колізії: Нариси, статті, інтерв'ю на теми політичної та етнічної психології / М. М. Слюсаревський. - К. : Гнозис, 1998. - 233 с. - С. 58-81. С. 68-81.

${ }^{5}$ Стефаненко Т. Г. Социально-психологические аспекты изучения этнической идентичности [Электронный ресурс] / Т. Г. Стефаненко. - М. : Флогистон, 1999. - Режим доступа : http://flogiston.ru/ articles/social/etnic.

${ }^{6}$ Психология развивающейся личности / Под. ред. А.В.Петровского; Науч-исслед. ин-т общей и педагогической психологии Акад.пед. наук СССР. - М.: Педагогика, 1987. - С. 20-21. 
ensured by a confident adequate, flexible and divergent behavior, which is called assertiveness.

Assertiveness, in our case, should be understood as a complex psychological phenomenon, "... which is a reduction factor in terms of manifestation of aggressiveness, violations of the psychological personality space and socio-psychological tension in society as a whole"7.

Summarizing the achievements of different authors, we can conclude that assertiveness is the best option between aggressive and passive behaviors. It is aimed at achieving a mutual balance of subjects of interaction, on the realization of their own interests in the conditions of realization of interests of all $8,9,10,11$.

\section{Formation of assertiveness as a means of balancing intercultural communication}

In previous publications ${ }^{12}$, the 7 th factor structure of social perception of ethnolinguistic communities was identified: "communicative engagement", "issuance of approval", "intimacy of personal space", "criticism", "neglect of others", "depreciation of relationships", "Attributive empathy".

The task of the research was to confirm that the identified factors of social perception are actualized in the context of the interaction between ethnolinguistic groups and their representatives in opportunistically conditioned social situations (extreme, subjectively significant, frusturing), which contributed to the strengthening of positive or negative components of social perception.

The format of the experiment used the technique of intragroup discussion in microgroups and the next intergroup discussion.

In order to fix the changes of the dependent variable, a questionnaire was used to assess the ethnic and linguistic categories at the beginning

7 Марчук Л. М. Асертивність як комплексна інтегральна характеристика особистості [Електронний ресурс] / Л. М. Марчук // Вісник Нац. академії Держ. прикордонної служби України. 2012. - № 5. - Режим доступу : http://archive.nbuv.gov.ua/e-journals/Vnadps/2012_5/12mlmiho.pdf.

8 Каппони В. Как делать все по-своему или Ассертивность - в жизнь / В. Каппони, Т. Новак. СПб. : Питер, 1995. - 186 с.

9 Леонтьев А. А. Ассертивность. Общение и деятельность общения / А. А. Леонтьев. - СПб. : Питер, 2008. - С. 160-215.

${ }^{10}$ Хохлова Е. В. Конструктивная агрессивность в формировании навыков ассертивного поведения студентов вуза : автореф. дисс. на соискание учен. степени канд. психол. наук : спец. 19.00.07 «Педагогическая и возрастная психология» / Е. В. Хохлова. - Нижний Новгород, 2008. - 26 с.

${ }^{11}$ Шамиева В. А. Ассертивность в структуре личности субъекта адаптации / В. А. Шамиева, К. И. Воробьева // Социально-гуманитарные науки на Дальнем Востоке : сб. статей. - Хабаровск: ДВГУПС, 2009. - № 4. - С. 79-83.

${ }^{12}$ Белавин С. П. Факторная структура социальной перцепции представителей этнолингвистических общностей / С. П. Белавин // Социосфера. - 2013. - № 4 ; ч. 1. - С. 156-161. - (РИНЦ, DOAJ, Google Scholar). 
of the experiment and after the end of the procedure. The results of the estimates of attractiveness proposed in the questionnaire categories by all participants in the experiment, after the procedure, were conventionally distributed on a language basis, and then subjected to statistical processing and further analysis and interpretation.

At this stage 150 students from three universities took part: Kyiv National Taras Shevchenko University, Kyiv National Economic University named after Vadym Hetman, Kyiv National Pedagogical University. MP Drahomanov. The participants in the pilot phase were students who were representatives of three different ethno-linguistic communities: Russian-speaking Russians, Russian-speaking Ukrainians, Ukrainian-speaking Ukrainians. With the help of purposeful influence, it was supposed to detect changes in the structure of the social perception of the participants in the experiment.

Eight experimental groups have been formed, with a relatively equal composition based on age, gender, nationality and language prevailing in personal communication. In seven groups, experimental influence was carried out to check the parameters of social perception within the limits of seven identified mechanisms (one in each group), and the eighth group was a control group. To measure subjective evaluation of ethnolinguistic categories, the subjects were asked to evaluate the degree of subjective attractiveness of these categories of people: four ethnic (Arabs, Ukrainians, Russians, Tatars), four language (Russian-language, Japanese-language, Ukrainian, and Tatar) and eight other (camouflage).

After the preliminary questionnaire, the subjects were offered a stimulating material in the form of text on sharp social themes - ethnic or linguistic confrontation - borrowed from online forums, newspaper articles and other media messages for intragroup discussion in microgroups and intergroup discussions. After the intragroup discussion in the microgroups and intergroup discussions, the subjects were offered a final questionnaire. According to the results of the experiment, it is possible to state statistically significant differences in some of the tested parameters.

Actualization of the factor "expectation of approval" caused among Russian-speakers the deterioration of the assessment of ethnic categories; Significant differences between the indices before and after the experiment at $p \leq 0.05$ were found.

We note that to a large extent this arose due to a decrease in the rating of the category of "Arabs" and somewhat "Ukrainians". As a result of the activation of the "expectation approval" factor, it turned out that 
the representations of the Russian-language subjects of the ethnic category "Arabs" and "Ukrainians" are to some extent "alien", that is, those that threaten their identity, in particular, the language's identity. The ethnic category "Arabs" is shown to them as "distant aliens," and the category "Ukrainians" is "close alien". The "close alien" is more personalized in subjective perception, from which the identity threat is felt more acutely. The difference between the subjective appeal of linguistic and ethnic categories is determined. If the Russian-speaking subjects do not expect approval from representatives of "other" ethnic groups, and perhaps avoid it, Ukrainian speakers do not expect approval from "other" language groups. At the same time, the Russian-language language slightly increased the assessment of the language categories after the experimental procedure.

Actualization of the factor "intimization of the personal space" caused a decrease in the assessment of language categories among the Ukrainian-language subjects; Significant differences between the indicators before and after the experiment were found at the level $p \leq 0.1$, first of all, due to a decrease in the assessment of the categories "Russianlanguage" and "Chinese-language". The categories "Russian-language" and "Chinese-language" are in the presentation of Ukrainian-language tested "strangers", perceived as threatening their linguistic identity. The updating of this factor leads to a strategy of avoiding Ukrainianlanguage communications with Russian and Chinese. Just as in the previous case, Chinese are perceived as "distant aliens," and Russianspeaking "close alien". For the Ukrainian-speaking population, the threat of ethno-identity is precisely Russian-speaking as "close aliens." The Russian-speaking language somewhat improved the attitude to both ethnic and linguistic categories, while Ukrainian-speakers turned it towards deterioration. Ukrainian-speaking people or distance themselves from foreign-speaking communities, or reduce the assessment of the linguistic characteristics of those who distance themselves from them.

Actualization of the factor of "neglect of others", led to a decrease in the assessment of language categories among Ukrainian-speaking Ukrainians; significant differences between the indices before and after the experiment were found at the level $\mathrm{p} \leq 0.1$, first of all, due to the reduction of the Tatars, and to a lesser extent, of the Chinese-speakers. This testifies to a certain "alienation" of the specified categories on a linguistic basis and their rejection and contempt. These categories are not perceived as a significant threat to the identity of Ukrainian-language 
subjects. In general, the evaluators have lowered their assessment of both ethnic and linguistic categories. It is noteworthy that, as opposed to a group of Russian-speaking subjects who lowered the assessment of the ethnic category "Ukrainians" (that is, they treat them as "close alien"), the attitude of Ukrainian-language subjects to the category "Russians" (average 3.8) did not change.

Actualization of the factor "expectation of approval" led to a decrease in the subjective evaluation of ethnic categories among Russian-language subjects, and the effect of the mechanism of "intimization of personal space" led to a decrease in the subjective assessment of representatives of language categories among Ukrainian speakers subjects.

Russian-speaking subjects, both Russians and Ukrainians, significantly reduced the rating of the very categories on an ethnic basis, while the Ukrainian speaking showed changes in the evaluated attitude (deterioration) to language categories, which indicates the greater sensitivity of Ukrainian- speaking subjects to the issues of language than ethnicity. This is due to the fact that Ukrainian speakers, identify themselves and endanger the language. And the representatives of the Russian-speaking community are likely to dominate the ethnic identity, as evidenced by the greater sensitivity to the estimated attitude to ethnicity. At the same time, the Russian speakers somewhat improves the attitude towards language categories and significantly worsens ethnic attitudes.

There were no significant differences in the control group for any parameter.

The experimental study of the factor structure of social perception and the possibilities for its optimization is due to the need to identify changes in the structure of social interaction of representatives of ethnolinguistic communities as a result of a specially organized influence on the estimated attitude to ethnic and linguistic categories as a result of manipulative intervention in the process of assertiveness training. It can be assumed that the optimization of the factor structure of the communicative interaction leads to moral and reflexive processes, aseriveness in interethnic relations, the development of understanding of the existence of the difference between people, tolerance and respect for the otherness, the ability to overcome stereotypes, prejudice, discrimination in interethnic relations, on the basis of language, nationality .

This definition allows us to build a program of training asertivity as a means of optimizing the factor structure of communicative interaction. 
The format of the molding experiment is the social-psychological training of assertiveness, a scenario of training sessions ${ }^{13},{ }^{14}$. Socio-psychological training is the most effective practice of psychological influence, is based on methods of group work, greatly facilitates and accelerates the process of acquiring the ability to find adequate ways of self-knowledge, understanding of others and skills of effective social behavior. Sociopsychological training optimizes the communicative capabilities of the person, more effectively promotes the occurrence of changes in the personality traits necessary for productive interaction in the polynational space, for a more mature reflection. The results of the forming experiment should be approximated to the model of the statistical conclusion about the existence of a causal relationship between the effect and the corresponding effect, that is, between independent and dependent variables of experimental study.

And therefore, the task of this training was to: experimentally confirm that the factor structure of the communicative profile is optimized in the process of a specially organized socio-psychological impact, which determines the moral-reflexive processes and assertiveness in interethnic relations; to contribute to the formation of moral reflection aimed at respecting a person, tolerant attitude and understanding of the existence of the difference between people, acceptance and respect for the otherness; develop: readiness for independent choice of means of establishing nondiscriminatory relations with others, means of realizing human rights at the ethnic, linguistic and general levels; the ability to overcome stereotypes, prejudices that degrade human dignity, discrimination in interethnic relations, language, etc.;

This effect of molding influence is especially needed in multi-ethnic and multicultural societies, which is the Ukrainian society.

Exactly the training of assertiveness that is most justifiable in solving the tasks set. It best determines the development of associativity in interethnic relations of tolerance and respect for the other, the ability to overcome stereotypes, bias on the basis of language, nationality, etc.

Interesting is the aspect of assertiveness, which is related to the ability to optimize the contradictions that arise in ethnic and ethnolinguistic communities and prevent the emergence of their extreme

\footnotetext{
13 Вачков И. В. Психология тренинговой работы: содержательные, организационные и методические аспекты ведения тренинговой группы / И. В. Вачков. - М. : Эксмо, 2008. - 416 с.

14 Милютина К.Л. Тренинг как процесс исследования и моделирования // К.Л. Милютина. Актуальні проблеми психології. Том Х. Випуск 4. / За ред. академіка С.Д.Максименка. - К.: Главник, 2008. - C. 54-60.
} 
forms: stereotyping, bias, stigmatization, discrimination, xenophobia. This phenomenon was laid on the basis of a molding experiment that should help the students to form a constructive way to find the way out of problem situations in communication, to respond optimally to criticism, the ability to resolutely speak to themselves and others, "no", to defend their own position, to achieve life goals, to be responsible for your own choice.

In the course of the molding experiment, the features of social perception and behavior in different conditions of interpersonal and group interaction were investigated, depending on the degree of psychological closeness (in the conditional local space, in a personally important situation in an open social environment), the experience of communication (the presence of stereotypes, prejudices, etc.), in conditions of false information (in accordance with the planned procedures).

The object of the formation experiment was the socio-psychological situation of the interaction of representatives of ethnolinguistic groups, and his subject - the optimization of manifestations of the factors of the communicative interaction of representatives of ethnolinguistic groups.

The experiment in the format of the training of assertiveness was implemented as an interaction organized by the researcher between the group of subjects and the experimental situation in order to establish the laws of this interaction and the variables on which it depends.

It should be emphasized that the participants in the sociopsychological training, belong to such ethnolinguistic communities: Russian-speaking Russians, Russian-speaking Ukrainians, Ukrainianspeaking Ukrainians.

87 students from higher educational institutions participated in the training: Berdyansk State Pedagogical University named after P. D. Osipenko and TG Shevchenko Chernigiv State Pedagogical University. The age range of the subjects is from 18 to 20 years. Five experimental groups were formed, with a relatively equal composition based on age, gender, nationality and language prevailing in personal communication, and one control group.

To measure the subjective evaluation of ethnic and linguistic categories, the subjects were asked to evaluate the degree of subjective attractiveness of such categories of people: ethnic (Arabs, Ukrainians, Russians, Tatars), linguistic (Russian-language, Chinese-language, Ukrainian, Tatar) and other (camouflage). The questionnaire included three categories of categories for ranking. 
The prevailing material for the experimental situation were conditionally indicated as the usual, and conditionally set psychologically dangerous, acute life events, when entering which, the testers can represent the most pronounced "deviations" in actions, forms of behavior from the generally accepted norms in the community.

First, it was necessary to find out how they manifest themselves in the conditional local space in a conditionally isolated group, when the active interaction of the individual with his immediate environment is limited only by an interpersonal relationship within this group and narrow-minded interests.

In such an alternative discipline may be the rigid status hierarchy and the structural division into distinct subgroups. They often have a low level of reciprocity of elections and a high rate of "neglected", but there may also be a high level of intra-group cohesion in relation to the vital events of the group in the proposed circumstances.

When carrying out measurements before and after the training, the conditional situation of getting into an unidentified island was proposed. It was necessary to rank the categories in the list of ethnic, linguistic, socially vulnerable and neutral evaluated on the basis of preferential treatment in the event of such a situation.

Second, it is important to establish how the "significant other" influences the choice, as the factor structure of communicative interaction manifests itself in the situation of taking into account the interests of "significant other". This term is used to identify a loved one that is important in personal life, such as a family member or friend. "Significant Other" affects a person in a certain way, which is expressed in a qualitative change in its semantic formations and behavioral activity.

In a training situation in the role of "significant other" act either brother or sister. For participants before and after the training, it was necessary to rotate the list of ethnic, linguistic, socially vulnerable and neutral rating categories on the basis of giving priority if the brother or sister would be friends or meet with one of the representatives of the specified categories.

Thirdly, how exactly do they manifest themselves in an open social environment, when interethnic interaction does not involve limiting contacts with one's own group, only one language of communication, etc. This implies the interaction of a society involving representatives of various ethnic groups and ethnolinguistic groups, and communication is also realized in other diverse relationships beyond this 
particular group as it is socially developed. Such groups are mainly focused on the primacy of emotional factors, as opposed to joint activities. They are characterized by a low indicator of mutual reference, that is, low indicators of mutual elections and alienation or neglect. In the third conditional situation, such a role was played by a student group, whose method of ranking was to select those for whom the subjects most favored the joint study in the class.

Control over independent and dependent variables was carried out by means of preliminary and control measurements of the attitude towards the ethnic and ethnolinguistic categories being evaluated. There was no molding effect in the control group, and the difference in time between the previous and the final measurements corresponded to the difference in the experimental groups.

The training provided one lesson in each group, which lasted for three hours, and, in addition to the tasks already defined, solved the search tasks of updating certain constructs of socio-psychological mechanisms and controlling changes.

The strategic training line can be defined as receiving new information about yourself, others, relationships with them; reconsideration of representations regarding the image of "I", "We" and "They"; building a new type of relationship with yourself, with others; consolidating the positive experience of communication and overcoming unconventional ways of interaction.

For the control of independent and dependent variables, a questionnaire has been developed that consists of three lists of such evaluable categories: representatives of ethnic, ethnolinguistic, socially vulnerable and neutral strata of the population. Measurement of the results took place "before" and "after" the training of assertiveness, in three series of measurements, taking into account the conditionally chosen situation, with the following instructions:

1) The first conditional situation (here and below): If you were on a deserted island, who would you be more willing to meet in such a situation? In each list of ten categories give first place to those who prefer, then the second most desirable of those who stayed and so on to ten.

2) The second conditional situation (here and below): In the same way, make a ranking of those who would prefer if the brother or sister would be friends or meet with any of the representatives of the specified categories. 
3) The third conditional situation (here and below): By the same method, rank the ones with whom you would be willing to study in one group at the university.

The first list included categories: Arabs, Russians, Bulgarians, students, Ukrainians, athletes, Tatars, Catholics, fellow countrymen, "four-eyes"

The second list consisted of the following rated categories: Russianspeaking; Bulgarian-speaking; Tatar-speaking; Ukrainian-speaking; polish-speaking; Japanese-speaking; people with gypsum on the leg; people with hearing aids; people with a scar on the face; good people.

The third list included categories: carefree, sad, cheerful, calm, indifferent, believers, active, redhead, singing, thoughtful.

The main methods during the training work were group discussion and simulation of the interaction situation in various modifications and in different configurations.

Group discussion is defined as a way of organizing communication of group members. It allows you to discuss the problem from the opposite views, to see the different positions of the participants about it. In a group discussion, an analysis of mental states in the set of possible situations that can cause uncertainty in their actions and judgments. Group members analyze personal experiences, resources and opportunities to overcome contradictions and prejudices in interethnic interaction. In the process of transforming the elements of the value-semantic sphere of the personality there is awareness of their own assertive positions.

The method of modeling the situation allows to actualize in the value-semantic sphere the person changes in the process of acquiring new experience. It helps the individual to acquire the ability to navigate in different situations, updates her readiness to experience conflicts and effects in interethnic communication, constructively, with the preservation of the integrity of their psychic world, self-esteem; overcome difficult life situations, defend their rights, demonstrating positivity and respect for others.

Under these conditions, it's important for every person to understand, understand the significance of another culture, unusual phenomena, and include new knowledge in his cultural arsenal, in the structure of his behavior and lifestyle, to find resources to overcome problems, frustration, personal involvement in the affairs of the state and society. It is important to realize the need to develop tolerance, unbiased attitude to others, and so on. 


\section{Characteristics of changes as a result of optimization of the factor structure of the communicative interaction of representatives of ethnolinguistic groups}

The obtained results before and after the experiment were initially subjected to the procedure of factor analysis by the method of the main components in various conditionally given situations of ethnolinguistic choice (3 series of measurements in accordance with the conditional situations described in the preceding paragraphs), which made a grouping of signs (representatives of ethnic, ethnolinguistic, socially vulnerable and neutral strata of society) based on the most significant correlations between them.

According to the results of factor analysis of the data obtained for the socio-psychological training, in the first conditional situation ("desert island"), 5 factors were distinguished. The total variance of the results of the factor analysis is $51.2 \%$, the cumulative $\%$ of the first three factors amounted to $33.5 \%$.

The first factor united the following categories: on one pole there were Bulgarians, Tatars, indifferent, careless, Arabs; on the other Ukrainians, Catholics, active, countrymen, singers. The categories of "strangers" have certain features of remoteness, indistinct (indifferent), contain ethnic categories that are not prevalent in the territory of Ukraine. This gives grounds for referring them to "distant foreigners."

The second factor combines categories on the basis of ethnolinguistic and neutral direction, namely: at one pole there were categories of united features, socially vulnerable strata of society with a slightly negative tone: people with gypsum on the leg, people with hearing aids, indifferent people with scar on face, students. That is, those that, of course, need sympathy and support, but cannot be classified as "we", although they can be defined as distant "their". At the other end, there were mainly linguistic categories: Polish-speaking, Bulgarian-speaking, calm, who also do not belong to the definition of "we", but rather belong to distant "alien", but abstract, and therefore safer. Although both poles combine the attribution to the "they" group, such a result shows a certain contrast between linguistic categories that do not require emotional expense and those who need help and altruism.

The third factor includes categories that are defined as neutral, so it makes no sense to analyze them thoroughly, but draws attention to the fact that ethnic and linguistic categories also differentiated in opposition to 
"their own - a stranger." At one pole - Japanese-speaking, and on the other side were Ukrainian-speaking and Russian.

The fourth factor combines ethnic and linguistic categories and also defined the bipolar structure where the categories were at one pole: Tatarspeaking, Bulgarian-speaking, Arabs, Russians, carefree, and on the other - "four-eyes", people from scar on the face, redheads, thoughtful. Here the ethnic and linguistic categories are opposed to those who always sympathize.

Interestingly, Russians were among the conditional category "they" on the same level, considering that most of the participants represent the Russian-speaking community in Ukraine, which does not identify itself with native speakers from another state. This can be explained by the fact that the participants of the training were born in an independent state, identify themselves with the Ukrainian community, and Russians may already be perceived as "close alien". Note that the relationship with "close alien" is always more acute, because the threat of identity is more realistic than a distant alien, the threat of identity, from which it has an abstract character (for example, Japanese).

In the fifth factor at one pole, those who speak Polish, and on the other - those who speak Russian. Such a distribution can characterize the presence of hard stereotypes according to ethnic and linguistic features. Other categories characterize the neutral features of social groups.

According to the results of factor analysis of the data obtained after the socio-psychological training in the first conditional situation, also 5 factors were distinguished. The total variance of the results of the factor analysis is $50.8 \%$, the cumulative percentage of the first three factors was $34.0 \%$.

In the first factor at one pole, along with neutral, the categories were grouped according to ethnic and ethnolinguistic characteristics, categories of people with special needs: Ukrainian-speaking, Arabs, people with gypsum in the foot, people with scar on their faces, people with hearing aids ; on the other side, along with the neutral categories, were Polishspeaking, Bulgarian-speaking, and Muslims.

The displacement of categories according to ethnic and ethnolinguistic features towards the socially vulnerable (before the training they were opposed) suggests the emergence of a somewhat sympathetic attitude to them, the idea that after the training the testers had confidence that, along with the socially vulnerable ethnic and ethnolinguistic categories, they deserved on a more tolerant attitude. 
In the second factor, ethnic, linguistic and neutral categories were united on one pole: Polish-speaking, sad, thoughtful, athletes; on the other side, along with neutral categories (thoughtful, cheerful, indifferent) representatives of socially vulnerable categories, namely people with hearing aids, with gypsum on the leg, as well as ethnic, for example, Ukrainians. The socially-vulnerable strata, to which Ukrainians joined the training, are opposed to Polish-speaking on one pole with neutral categories. That is, after the training, Ukrainians were more acceptable to compassion and leniency on themselves.

The third factor is presented: at one pole - Tatars-speaking, Tatars, Russian-speaking who represent the categories "they", that is, "not their own"; on the second: Ukrainians, Ukrainian-speaking, singing, active, that is, "we" or "ours".

Fourth and fifth factors did not reveal evidence for analysis.

Summarizing the results of factor analysis for the first conditional situation, we can determine the tendencies of weakening of negativism, more lenient attitude to the ethnic and linguistic categories. There is a general tendency to mitigate stereotyped ethnic and ethnolinguistic indications. This is confirmed by a combination of factors at one pole, which contrasted in measuring with the training procedure, namely, the categories defined by representatives of socially vulnerable social strata and ethnic and ethnolinguistic categories.

The next step was to create two new variables: the first included all ethnic categories, and the second one - all languages. A linear clustered model based on the MANOVA procedure was constructed to compare the average "before" and "after" experiments in the first series of measurements, in the pre-established ethnic and linguistic variables, among the representatives of ethnolinguistic communities. The criterion of significance was Bonferon's criterion chosen as the most sensitive to the number of measurements.

In the first situation, in the ethnic variable, significant differences between the "before" and "after" experiments were detected. The increase of subjective evaluation of ethnic categories among the Russians tested was revealed. That is, assertiveness in interpersonal and intergroup relations allows optimizing the parameters of social perception. In the linguistic variable significant differences between the "before" and "after" experiments were identified. The subjective evaluation of linguistic categories in groups of Russians and Russian-speaking Ukrainians at the level $\mathrm{p} \leq 0.1$ was found to decrease. Apparently, for Russian-speaking tested language 
identity is a significant or even painful sign. According to the results of the calculations revealed a tendency to improve the attitude towards ethnic communities, and some deterioration of the attitude to the linguistic.

In the second conditional situation ("significant other"), based on the results of factor analysis of the data obtained "before" the procedure of socio-psychological training in the process of polling the total number of test participants training, identified 5 factors. The total variance of the results of the factor analysis is $53.969 \%$, the cumulative percentage of the first three factors was $34.508 \%$.

The first factor is represented: at one pole there were Bulgarianspeaking, Japan-speaking, Tatar-speaking, Arabs, Russians, indifferent; on the other side there were "four-eyes", singers, good people, people with gypsum on the leg. Ethnic and linguistic categories that are at one pole indicate the actualization of ethnolinguistic identity.

The third factor is represented by the following categories: Japanspeaking, fellow countrymen, Catholics, and Ukrainian-speaking at one pole; at the other poles - Arabs, Bulgarian-speaking, careless, Bulgarian, Russians. This contrast shows a comparison of the far and fairly abstract "alien" and more or less "theirs" at one pole, which is consistent with the provisions on the need for psychological safety set forth in the first section. On the other side of the pole are opposing this category of close "strangers", which, constitute a greater threat to the identity of the testers.

In the fourth factor at one pole were Bulgarians, Tatars, sad, Russianspeaking; at the other end, good people, Catholics, calm, people with a scar on their faces, believers. At one pole in this factor, they became significant for the tested categories, which are presumably part of the category "close alien".

The second and fifth factors did not reveal evidence for analysis.

According to the results of factor analysis of data obtained after the socio-psychological training, in the second conditional situation, 5 factors were distinguished. The total variance of the results of the factor analysis is $53.492 \%$, the cumulative percentage of the first three factors amounted to $35.775 \%$.

The first factor is represented by the following categories: at one pole: Bulgarian-speaking, believers, Polish-speaking, Japan-speaking, Tatar-speaking, cheerful, fellow countrymen; at the other poles: people with gypsum on the leg, people with hearing aids, carefree, indifferent, people with scar on their faces, students. Conflict within a single factor of 
socially vulnerable strata and categories that can be generally called "others", or even more or less distant "strangers", indicates a certain degree of social exclusion of the subject.

The second factor is represented by the following categories: at one pole: active, thoughtful, singing, "four-eyes", people with scar on the face, Ukrainian-speaking; at the other poles: Japan-speaking, careless, indifferent, Bulgarians, Arabs, cheerful, sad. Within the limits of this factor the opposition of ethnic and linguistic categories, together with the neutral categories, reveals a certain threat of Ukrainian language from the side of "distant foreigners".

The third factor is represented by the following categories: at one pole: Japan-speaking, Tatar-speaking, Catholics, Redheads, fellow countrymen; at the other poles: Arabs, Russians, athletes, Russianspeaking. Contradiction of the categories of "distant aliens" and "close alien" confirms that with "distant foreigners" under certain conditions one can understand and do not constitute a perceived threat, and "close alien" - clearer, more tangible, and therefore cause a more acute reaction.

Fourth and fifth factors did not reveal evidence for analysis.

According to the results of the factor analysis to the sociopsychological training in the third conditional situation, 5 factors were distinguished. The total dispersion is $56.806 \%$, the cumulative percentage of the first three factors is $37.952 \%$.

The first factor is represented by the following categories: at one pole: Polish-speaking, Bulgarian-speaking, Arabs, Tatar-speaking, Japanspeaking, Bulgarians, sad; at the other poles: people with hearing aids, people with gypsum on the leg, people with scar on the face, "four-eyes", Ukrainians, Redheads.

The second factor is represented by the following categories: at one pole: active, Ukrainian, good people, thoughtful, Redheads, singing; at the other poles: Bulgarian-speaking, Arabs, Tatar-speaking, indifferent, sad, careless. Within this factor, we see the opposition of Ukrainians who are on the same pole with positively connotative categories, other ethnic and linguistic categories, with mostly negative connotations.

The fourth factor is represented by the following categories: at one pole: thoughtful, calm, athletes, Russian-speaking, Russians; at the other poles: people with hearing aids, "four-eyes", good people, Tatars. Regarding this factor, one of the poles along with the categories of Russian-speakers and Russians, got other signs that have a positive connotation. On the other side of the pole - together with the Tatars were 
the categories of socially vulnerable, which can be understood as a rather lenient attitude.

Third and fifth factors did not reveal evidence for analysis.

According to the results of the factor analysis after the sociopsychological training in the third conditional situation, 5 factors were distinguished. The total variance of the results of the factor analysis is $55.669 \%$, the cumulative percentage of the first three factors was $37.440 \%$.

The first factor is represented by the following categories: at one pole: singing, Ukrainian-speaking, “four-eyes", active, thoughtful, fellow countrymen, Ukrainians, people with scar on his face; at the other poles: Bulgarian-speaking, Bulgarians, sad, careless, Arabs. In the context of this factor, we see a socially vulnerable one at the same time with Ukrainianspeaking, which is understood as a lenient attitude towards these categories; On the other hand, they are opposed to other ethnic and linguistic categories that are understood as "not their own".

The second, third, fourth and fifth factors did not reveal evidence for analysis.

After conducting factor analysis in the third series, we again compared the mean values of the rank of ethnic and ethnolinguistic categories by the MANOVA procedure. In the ethnic variable, significant differences were found in the group of Russian-speaking Russians at the level $p \leq 0.1$, that is, there is an increase in the subjective assessment of ethnic categories. In the linguistic variable significant differences were found in the group of Russian-speaking Ukrainians at the level $p \leq 0,1$, that is, there is an increase in the evaluation of these categories. We also see some deterioration in the evaluation of linguistic categories in the group of Ukrainian-speaking Ukrainians.

The general tendency to mitigate stereotyped guides by ethnic and ethnolinguistic features is revealed. This is confirmed by a combination of features at one pole, previously contrasted with the measurement of the training procedure, namely, the categories that define the representatives of socially vulnerable social strata and ethnic and ethnolinguistic categories.

The general attitude towards the estimated ethnic categories in most cases has improved due to the fact that ethnicity is a rather abstract category. The structure of one ethnic group may include many national groups, but their representatives often have a narrow, national identity, so the attitude to ethnic belonging is not so acute. 
In contrast, the attitude to language categories can be divided into three components: the attitude towards "close ones" - Russian-speaking and Ukrainian-speaking in general have improved; the attitude towards "close aliens" - the Bulgarian-speaking and Tatar-speaking categories of evaluation generally deteriorated, the attitude towards "distant foreigners" - rather abstract for the experienced, Polish-speaking and Japan-speaking, has generally improved.

Language is the most significant sign of division into "their" and "strangers", but with some language groups, they are tested or met every day, or at least they know about their presence next to them, and with others - either they are not at all, or so infrequently, that these groups acquire a rather abstract, blurred status of "distant strangers", as Polish and Japanese speakers. So the attitude to "close alien" will always be sharper than to "distant", because "close alien" is always more dangerous.

Reducing the effects of negative stereotypes in the process of perceiving "the other" and the "alien" groups requires the participants to engage in the awareness of their own bias and the desire to change their beliefs based on the values of tolerance, justice, equality and conscience.

In this way, we were able to determine what changes in the social identity of youth occur as a result of one or another factor and whether these changes are related to its influence.

\section{CONCLUSIONS}

Conducting a molding experiment to optimize the intercultural communication of representatives of ethnolinguistic communities in various conditionally prescribed situations, the method of sociopsychological training of assertiveness made it possible to draw separate conclusions.

The general tendency of softening of stereotypical installations according to ethnic characteristics is observed. It is established that the severity of the factors of social perception is actualized and optimized in the process of social interaction between different ethno-linguistic groups or their representatives in different social conditions and situations, provided that they are organized in interaction and assertive behavior.

The identified components of the factor structure of social perception can be optimized in the process of specially organized influence (training of assertiveness), which results in the reduction of the effects of negative stereotypes in the process of perceiving the "other" and "alien" groups and 
requires the participants to understand the interactions of their own bias and the desire to change their beliefs. , based on the values of tolerance, justice, equality and conscience.

Experimental way has been found that optimization of communicative interaction leads to moral and reflexive processes, development of understanding of the existing difference between people and communities on the grounds of language and ethnicity, determines tolerant attitude and respect to the otherness, ability to overcome stereotypes, prejudice, discrimination in interethnic relations. Experimental impact on representatives of ethnolinguistic communities has shown that updating of the factor "expectation of approval" led to a decrease in the assessment of ethnic categories among Russian-speaking subjects; actualization of the factors "intimization of personal space" and "neglect of others" led to a decrease in the assessment of language categories in Ukrainianspeaking subjects.

It is revealed that for Russian-speaking tested language identity is more significant; there was a decrease in the subjective evaluation of linguistic categories in Russian and Russian-speaking Ukrainians. In the ethnic variable in the Russian-speaking Russian group, the subjective assessment of ethnic categories has increased.

The results of the experiment made it possible to conclude that the most sensitive to the influence of the components of social perception in the conditions of ethnolinguistic choice are situations of an open social environment, conditional localized space, the ideal representation of a subjectively significant "other".

It is shown that direct interethnic communication does not necessarily contribute to the optimization of social stereotypes and the destruction of prejudices. Awareness of the similarity of the properties and values of "their" and "strangers" leads to positive changes in perception.

\section{SUMMARY}

The article is devoted to studying the results of experimental influence on representatives of various ethnic and linguistic communities of modern Ukraine, the program and the general course of the experiment are presented, certain conclusions are made.

The general tendency of softening of stereotypical installations according to ethnic characteristics is observed. It is established that the severity of the factors of social perception is actualized and optimized in the process of social interaction between different ethno-linguistic groups 
or their representatives in different social conditions and situations, provided that they are organized in interaction and assertive behavior.

It is revealed that for Russian-speaking tested language identity is more significant; there was a decrease in the subjective evaluation of linguistic categories in Russian and Russian-speaking Ukrainians. In the ethnic variable in the Russian-speaking Russian group, the subjective assessment of ethnic categories has increased.

It is shown that direct interethnic communication does not necessarily contribute to the optimization of social stereotypes and the destruction of prejudices. Awareness of the similarity of the properties and values of "their" and "strangers" leads to positive changes in perception.

\section{REFERENCES}

1. Белавин С. П. Факторная структура социальной перцепции представителей этнолингвистических общностей / С. П. Белавин // Социосфера. - 2013. - № 4; ч. 1. - С. 156-161. - (РИНЦ, DOAJ, Google Scholar).

2. Васютинський В. О. Російськомовна спільнота в Україні: загрози ідентичності і постави щодо інтеграції / В. О. Васютинський // Науковий вісник Львівського державного університету внутрішніх справ. - Львів, 2008. - Вип.1. - С. 37-45.

3. Вачков И. В. Психология тренинговой работы: содержательные, организационные и методические аспекты ведения тренинговой группы / И. В. Вачков. - М. : Эксмо, 2008. - 416 с.

4. Голота А. С. Соціально-психологічні особливості етнонаціональної ідентичності українсько-російських білінгвів : автореф. дис. ... канд. психол. наук : 19.00 .05 «Соціальна психологія; психологія соціальної роботи» / А. С. Голота - К., 2012. - 18 с.

5. Донцов А. И. Язык как фактор этнической идентичности / А. И. Донцов, Т. Г. Стефаненко, Ж. Т. Уталиева // Вопросы психологии. - 1997. - № 4. - С. 75-86.

6. Каппони В. Как делать все по-своему или Ассертивность в жизнь / В. Каппони, Т. Новак. - СПб. : Питер, 1995. - 186 с.

7. Леонтьев А. А. Ассертивность. Общение и деятельность общения / А. А. Леонтьев. - СПб. : Питер, 2008. - С. 160-215.

8. Марчук Л. М. Асертивність як комплексна інтегральна характеристика особистості [Електронний ресурс] / Л. М. Марчук // Вісник Нац. академії Держ. прикордонної служби України. - 2012. - 
№ 5. - Режим доступу : http://archive.nbuv.gov.ua/e-journals/ Vnadps/2012_5/12mlmiho.pdf.

9. Милютина К.Л. Тренинг как процесс исследования и моделирования // К.Л. Милютина. - Актуальні проблеми психології. Том Х. Випуск 4. / За ред. академіка С.Д.Максименка. - К.: Главник, 2008. - С. 54-60.

10. Психология развивающейся личности / Под. ред. А. В. Петровского; Науч-исслед. ин-т общей и педагогической психологии Акад.пед. наук СССР. - М.: Педагогика, 1987. - С. 20-21.

11. Слюсаревський М. М. Ілюзії і колізії: Нариси, статті, інтерв'ю на теми політичної та етнічної психології / М. М. Слюсаревський. - К. : Гнозис, 1998. - 233 с. - С. 58-81. С. 68-81.

12. Стефаненко Т. Г. Социально-психологические аспекты изучения этнической идентичности [Электронный ресурс] / Т. Г. Стефаненко. - М.: Флогистон, 1999. - Режим доступа: http://flogiston.ru/articles/social/etnic.

13. Хохлова Е. В. Конструктивная агрессивность в формировании навыков ассертивного поведения студентов вуза : автореф. дисс. на соискание учен. степени канд. психол. наук : спец. 19.00.07 «Педагогическая и возрастная психология» / Е. В. Хохлова. Нижний Новгород, 2008. - 26 с.

14. Шамиева В.А. Ассертивность в структуре личности субъекта адаптации / В. А. Шамиева, К. И. Воробьева // Социальногуманитарные науки на Дальнем Востоке : сб. статей. - Хабаровск : ДВГУПС, 2009. - № 4. - С. 79-83.

\section{Information about the author:}

Bielavin S. P.

PhD in Social Psychology, Associate Professor at the Department of Psychology and Pedagogy of the Scientific and Humanitarian Institute of the V. I. Vernadsky Taurida National University 